\title{
SCENARIO PLANNING AS APPROACH TO IMPROVE THE STRATEGIC PERFORMANCE OF MULTINATIONAL CORPORATIONS (MNCS)
}

\author{
Ahmad Nasser ABUZAID \\ Department of Business Administration, Faculty of Business, Mutah University, Alkarak, Jordan \\ E-mail:ahmad.abuzaid2007@yahoo.com
}

Received 05 June 2018; accepted 04 October 2018

\begin{abstract}
The primary purpose of this study was to explore the relationship between scenario planning and strategic performance. The data was collected from 121 Multinational corporations operating in Jordan by using a questionnaire. Pearson correlation and the partial least squares (PLS) methodology for factor analysis and path modelling was used to test the study hypotheses. The study found a positive and statistically significant relationships between scenario planning and the four components of strategic performance: financial performance, customer performance, learning and growth, and internal business processes. Based on these findings, the study recommends that managers should apply scenario planning practices to enhance the levels of strategic performance in their companies. Additionally, managers should raise the awareness of their employees regarding the importance of both scenario planning and strategic performance. Moreover, managers should provide their employees with adequate training courses in relation to acquire the knowledge and build their skills in the field of scenario planning. Finally, managers should use the diagnostic instruments that developed by previous research to assess a company's strategic performance and scenario planning practices, identify managerial practices that need to be implemented or improved, and determine the resources that might realistically be required to build a better scenario planning process and promote strategic performance. Much more research and studies need to be performed in this budding subject. Links among scenario planning and another organizational topics and outcomes need to be searched.
\end{abstract}

Keywords: scenario, scenario planning, strategic performance, MNCs, Jordan.

JEL Classification: M10, C53, O21, F23.

\section{Introduction}

The challenges facing multinational corporations in the business environment can be described by the "volatility, uncertainty, complexity and ambiguity" (Bennett and Lemoine 2014). Looking at these challenges, we can see that traditional strategic planning tools may lack an essential future-related perspective (Hartmann and Stillings 2015). Traditional methods often rely either on past experiences or at most on snap shots of the present when describing the business environment. Therefore, multinational corporations increasingly attempt to cope with this risk by trying to understand and manage the future (O'Brien and Meadows 2013, Bowman et al. 2013). In addition, the rapid pace at which changes in economic and business conditions are occurring has been highlighted as a major challenge for multinational corporation. Such a change directly impedes multinational corporation's ability to implement their intended strategy. Within this environment, managing uncertainty becomes especially important (Simons 1990). Scenario planning as a business activity has gained increased traction as a tool for addressing complexity, uncertainty, and the unknown (Haasnoot et al. 2013, Oliver and Parrett 2017).

Scenario planning is increasingly well established as a means of preparing individuals and organizations to respond to the uncertainty and chaos of the global work environment (Rigby and Bilodeau 2007, Bradfield et al. 2005, Chermack 2011, Durance and Godet 2010, Schwartz 1996, Wack 1985, Chermack et al. 2017, Kahane 2012, Ramirez and Wilkinson 2016, Schoemaker 1995, Cox Landolt 2000,

Copyright $\odot 2018$ The Authors. Published by VGTU Press.

This is an Open Access article distributed under the terms of the Creative Commons Attribution License (http://creativecommons.org/licenses/by/4.0/), which permits unrestricted use, distribution, and reproduction in any medium, provided the original author and source are credited.. 
Malaska et al. 1984). Therefore, scenario planning is deemed a useful instrument that assist multinational corporations to be ready for potential probability, and improves their flexibility (Argueta et al. 2016), enhances their innovation capabilities (Hiltunen 2009), helps multinational corporations to understand the environment and determine the interactions between sundry future trends and events (Martino 2003) in addition to predict the consequences of a specific decision or choice (Strauss and Radnor 2016).

However, because multinational corporations leaders are under pressure to justify the investment of resources, some type of criterion needs to be developed that shows a clear link between scenario planning and strategic performance. One possible step in providing this link may lie in establishing the actual effect scenario planning has on the strategic performance (Puthenveetil 2016). Some scholars like (Chermack and Lynham 2002, Hartmann and Stillings 2015) pointed out that empirical evidence of the effect of scenario planning on strategic performance of multinational corporations is almost nonexistent. In fact, this lack of an evidence regarding the influence of scenario planning on strategic performance may indicate to a greater gap in the body of knowledge that is used to develop of scenario planning and inform of the practice. Therefore, the importance of understanding how scenario planning may influence and improve performance has stimulated calls to further explore the impact of scenario planning on strategic performance (e.g., Phelps et al. 2001, Visser and Chermack 2009, Lindgren and Bandhold 2009, Chermack 2011, Zahradnícková and Vacík 2014). Thus, the current study tries to explore the link between scenario planning and strategic performance in Jordanian context.

\section{The study problem}

In today's global economy, the main players are multinational corporations. They are the exporter of major capital, technology transfer, knowledge, expertise, and international market access. MNCs have a fundamental effect on technology transfer social and infrastructure development. It assists in replacing declining market sectors, activating employment, and increasing wages, Thus, having social and cultural effect if the investment is directed toward non-traditional sophisticated product (Summit 2002). One of the main challenges that face the multinational corporations today is the state of uncertainty about market trends and the business environment in which they operate. Due to uncertainty and rapid changes in the business environment MNCs have become seeks to maintain their sustainability and growth by improving strategic performance. Scenario planning is considered a valuable tool to manage uncertainty. Therefore, the current study tries to answer the following question:
Is there a relationship between scenario planning and strategic performance?

\section{The study significance}

Until now, there has been few empirical research that related to the direct relationship between scenario planning and its influence on strategic performance, and, therefore, the current study has been useful in its contribution to the literature of scenario planning. More specifically, This study contributes to the related literature in terms of:

Supporting the notion that scenario planning has a significant effect on strategic performance; and

Providing empirical evidence regarding the role of scenario planning in improving the strategic performance.

\section{Literature review}

\subsection{Scenario planning}

Organizations have used scenario planning as an integral part of strategic planning process, but is often confused with prediction methodologies like futurism or forecasting (Azalia and Stein 2017, Lindgren and Bandhold 2009, Ramirez and Wilkinson 2016). There is not a universally accepted definition for scenario planning, so it was difficult to find a clear definitions that embodied the correct meaning of scenario planning concept (Chermack et al. 2001). Based on definitions provided by (Porter 1998, Ringland 1998, Schwartz 1996, Schoemaker 1995) Chermack and Lynham (2002) developed the following integrated definition:

Scenario planning is a mechanism in which decisions about the future may be played out in order to change current thinking, improve decision making, and enhance human and organization learning through a process of positioning several informed, reasonable, and imagined alternative future environments.

More recently, Scenario planning defined as a methodology that uses the inherent human capacity for imagining futures to better understand the present situation and to identify possibilities for new strategy (Ramirez and Wilkinson 2016) and as a conceptual tool used to address complexity, uncertainty, and the unknown through the consideration of one to many potential future states, activities, situations, events, decisions, and/or occurrences (Schulaka 2017).

There are several general benefits ascribed to scenario planning. Many scholars indicated that scenario planning helps to find innovative and robust solutions to address complex problems and uncertain futures (Arafet and Ali 2018, Bennett et al. 2016, Burt et al. 2017, Schwartz 1996, van der Heijden 1996). In addition, scenario planning enables managers to cope with uncertainty by helping to understand the environment and its systems, how to deal with 
potential problems by thinking through them, and by providing alternative mental models (Burt et al. 2006, O’Brien and Meadows 2013, van der Heijden 1996). Moreover, scenario planning enables organizations to foster dynamic capabilities to respond to the environmental changes and adapt to them (Ramirez and Wilkinson 2016, Swanson 1998). Finally, scenario planning helps improve decision making in the present, since the scenarios serve the purpose of evaluating current strategic options to develop alternative strategies to handle possible futures, and select the suitable and right strategy among of a multiple correct strategies (Ramirez and Wilkinson 2016, Robbins 1995, Wood 1997).

The results of empirical research confirmed that the scenario planning have many outcomes in the organizational context. The first major outcome of scenario planning identified by previous research results is changed thinking and mindset (Bradfield et al. 2016, Chermack et al. 2017, Chermack and Lynham 2002). This outcome considers the mental models which are organizationally important to all organizations because they internally provide a means for interpreting events and externally provide an understanding about the worldview of an organization (Wack 1985). The second category of scenario planning outcomes recognized by previous research results is improved decision making (Chermack et al. 2017, Chermack and Lynham 2002, Phadnis et al. 2016). This category concerns the linkage between scenario planning and better decision making in an organization concerning strategic issues (Phadnis et al. 2016, van der Heijden 1996). Scenario planning allows organizations to act on a new situation rather than react to it. This outcome also ties in with more robust strategy, since strategy developed with the aid of scenario planning will be more productive, or able to be changed quickly, across a variety of futures (Ramirez and Wilkinson 2016, van der Heijden 1996). The last major outcome of scenario planning demonstrated by previous research results is enhanced organizational learning (Chermack et al. 2017, Chermack and Lynham 2002). This outcome involves rolling the people of the organization into ongoing strategic conversations. This is a characteristic of the intuitive approach where the scenario planning process becomes an integral part of the organization so that a true learning organization, such as those detailed by Senge et al. (1994), is developed.

Borjeson et al. (2006) identified three main categories of scenarios, as is described below:

First; Predictive scenarios: are scenarios that formulated to answer to questions in the following format: "What will happen?" the purpose of predictive scenarios is to try to foresee what is going to happen. The types of predictive scenarios are include forecasts and what-if scenarios.

Second; Explorative scenarios: answer to the question "What can happen?" The purpose of these scenarios is to predict the future from a variety of perspectives and opinions. The types of explorative scenarios are external and strategic. external scenarios respond to question "What can happen to the development of external factors?". Strategic scenarios are respond to the question "What can happen if we act in a certain way??.

Third; Normative scenarios: respond to the question "How can a specific target be reached?". The types of normative scenarios are include preserving and transforming scenarios. normative preserving scenarios answer to the question "How can the target be met, by adjustments to current situation?". Transforming scenarios answer to the question: "How can a target be met, when prevailing structure blocks necessary changes?”.

The current study utilized (Borjeson et al. 2006) classification of scenario planning, since it is the only and the most popular classification of scenario planning that cited by the literature in order to measure the scenario planning.

\subsection{Strategic performance}

The performance evaluation is a systematic review process executed to assist an organization attain a particular goal. In order to assist the companies to manage its resources in effective way and measure its performance in relation to its objectives, performance evaluation should be a part of the management and control system (Wu and Hung 2008). However, strategic performance indicates to the successful attainment of a company's strategic goals (Zou and Cavusgil 2002). The concept of strategic performance includes both organizational performance as well as organizational effectiveness (Chakravarthy 1986). In general, strategic performance shows the competitiveness of an organization and covers the most influential position between competitors in achieving a foothold in the market place, increasing the consciousness of the company and responses to those competitive actions and challenges which were established by competitors (Chung 2011). According to (Chung et al. 2015) strategic performance promotes the organizational learning process and assists an organization to make competitive and unique abilities in operational arena. Additionally, strategic performance leads the competitive positions of organizations, and presents details in relation to the overall performance of the organization: performance relative to competitors and performance relative to other organizations of the same type in the market and industry in general (Madison et al. 2014).

Many scholars like (Chandler 1962, Clarke 1987, Miles and Snow 1978) pointed out that the notion of strategic fit should be considered when defining strategic performance, due that strategic fit underlies most of the dominating strategic literature as a vital notion for organization performance, as well as, strategy is concerned with establishing a fit between an organization's external environment and its internal resources and structures (Porter 1980, Porter 1985, 
Prahalad and Hamel 1990, Collis and Montgomery 1995), substantiating the importance of strategic fit.

However, traditional performance evaluation metrics are limited in their assessment of overall performance because they are often based only on financial performance (Booth 1996). As a result, the traditional evaluation of financial performance is considered as an not an comprehensive or effective measure, nor is it a holistic evaluation approach. In order to overcome these shortcomings Kaplan and Norton (1992) proposed the balanced scorecard model.

The balanced scorecard model focuses on both financial and non financial performance, as well as, takes into account the organization's vision and strategies. Briefly, it monitors competitiveness and long-term financial metrics while also highlighting the value of short-term financial performance (Kaplan and Norton 1992, Kaplan and Norton 1996, Kaplan and Norton 2001). Pinero (2002) pointed out that the purpose of the balanced scorecard model is to assist the organization attain its objectives through measuring its tangible assets by the traditional financial metrics, in addition to evaluate its intangible assets and intellectual capital by three perspectives namely customers, learning and growth, and internal processes. Thus, the strategies of organization are tested by both financial and non-financial metrics, based on actual data for a holistic assessment.

According to Wheelen and Hunger (2012) the financial perspective of balanced scorecard is concerned with the question how do we appear to shareholders?. Whereas the customer perspective is concerned with the question how do customers view us?. Whilst the internal business processes perspective is concerned with the question what must we excel at?. Finally, The learning and growth perspective is concerned with the question can we continue to improve and create value?.

This study utilized Kaplan and Norton's (2004) balanced scorecard model to measure strategic performance. The balanced scorecard model has received much attention in organization and management literature (Pinero 2002), and continues to be heavily utilized for research (e.g. AlTarawneh 2018, Chen et al. 2011, Grigoroudis et al. 2012, Jusoh et al. 2008, Mitchell et al. 2013, Sharabati and Fuqaha 2014, Sim and Koh 2002).

\subsection{Scenario planning and strategic performance}

\subsubsection{Financial performance}

The financial performance within the balanced scorecard includes many criteria like: achieving profits, increasing the revenues, and maximizing the investors wealth (Kaplan and Norton 2004). Empirical results of previous research found that there is a positive relationship between the financial performance in terms of faster growth, higher return on capital, and higher profitability and scenario planning, in addition, the results confirmed that scenario planning can be used as a tool to improve financial performance (Phelps et al. 2001). Moreover, empirical results of previous research indicated that the practice of scenario planning promotes the organizational learning practices (Chermack et al. 2017, Chermack et al. 2006, Inayatullah 2009) and thus leads to better financial performance (Aliya and Maheen 2017, Kim et al. 2017, Prieto and Revilla 2006). Therefore, the first hypothesis is:

Ha1: There is a relationship between scenario planning and financial performance.

\subsubsection{Customer performance}

Kaplan and Norton (1996) indicate that the customer performance can be measured by: market share, customer: retention, acquisition, satisfaction and profitability. Empirical results of previous research found that scenario planning leads to increase the sales level and market share of the organizations by introducing the unique services/products (Kuye and Oghojafor 2011). In addition, the results of previous studies demonstrated that scenario planning leads to increase innovation capabilities (Sarpong and Maclean 2011), thus, increases the level of customer satisfaction and customer value (Abdulai et al. 2018, Weng et al. 2012) and helps to increase the organization ability in regards customer retention (Kyei and Bayoh 2017). Therefore the second hypothesis is:

Ha2: There is a relationship between scenario planning and customer performance.

\subsubsection{Internal business processes}

Internal business processes reflect the organization's ability to innovate, employ creativity, utilize the appropriate technology, and enhance adaptability in order to excel at activities that create value (Kaplan and Norton 2004). Previous studies found that scenario planning leads to increase the innovation capabilities of the organization (Sarpong and Maclean 2011). In addition, scenario planning enhances the creativity within the organizations, and provides a useful tool in identifying technologies that are potentially disruptive; mapping out possible development paths for such technologies; and developing organizational capabilities to exploit the opportunities presented by disruption (Drew 2006). Moreover, Scenario planning allows organizations to act on a new situation rather than react to it, thus, enhance its ability to manage emergencies (Ramirez and Wilkinson 2016, van der Heijden 1996). Therefore the third hypothesis is:

Ha3: There is a relationship between scenario planning and internal business processes

\subsubsection{Learning and growth}

Learning and growth focuses on organization's ability to solve problems, increase employees efficiency, and develop 
their capabilities and skills through training (Kaplan and Norton 1996). The results of previous studies found that scenario planning helps to find innovative and robust solutions to address complex problems and solve it in effective manner (Arafet and Ali 2018, Bennett et al. 2016, Burt et al. 2017, Schwartz 1996, van der Heijden 1996). In addition, scenario planning leads to enhance the efficiency of organization's management through the development of leadership capability and capacity (Glick et al. 2012). Moreover, scenario planning considered as a training tool that contributes to increase the skills of employees and development of human resource in general (Glick et al. 2012). Therefore the fourth hypothesis is:

Ha4: There is a relationship between scenario planning and learning and growth.

\section{Study method and design}

A quantitative method was chosen for the current study. Specifically the survey design, data were collected using a questionnaire. Pearson correlation coefficient was computed to determine the relationship between the study variables. In addition, Partial least squares (PLS) methodology was employed to test the relationships between all constructs in the structural model. PLS provides a useful data analytic strategy when the researcher is faced with small samples, subjective observations of data, or nascent or emerging theory, which are common in group and organization research (Sosik et al. 2009). PLS is also effective for data analysis when Multicollinearity could be present (Chong and Jun 2005).

\section{Population and sample}

The study population consisted of 121 Multinational Corporations operating in Jordan. The study sample included all the study population. The sampling unit and analysis consisted of CEOs of the target companies.

\section{Data collection procedures}

Data were collected via self-administered survey available on paper. The main round of survey was conducted in Jordan between January and February, 2018. The data were collected thru drop-off and pick up questionnaire as the most suitable procedure to collect data in the Middle East region to enhance the response rate (Al-Ma'aitah 2018). A cover letter was included with the questionnaires that explained the purpose of the survey.

\section{Measures}

All scales adopted the 5-point Likert-type response format. The researcher used 37 items to obtain respondents answers that best represented their perceptions regarding scenario planning and strategic performance. (See Appendix A.)

Scenario Planning: The researcher used the 17-item scale developed based on the work of (Hojer et el. 2008, Borjeson et al. 2006) to measure the perceptions of CEOs toward scenario planning (ranging from $1=$ strongly disagree, to $5=$ strongly agree). The items (1-6) developed to measure explorative scenarios, while the items (7-11) developed to measure normative scenarios, finally, the items $(12-17)$ developed to measure predictive scenarios.

Strategic Performance: The researcher used the 20 -item scale adopted from (Sharabati and Fuqaha 2014, Chen et al. 2011, Kaplan and Norton 2004) to measure the perceptions of CEOs toward strategic performance (ranging from $1=$ strongly disagree, to $5=$ strongly agree). Financial performance was measured by the items (18-22), customer performance was measured by the items (23-27), internal processes were measured by the items (28-32), finally, learning and growth was measured by the items (33-37).

Demographic Variables: The researcher used 4 demographic questions regarding respondents (Gender, Age, Experience; and Education).

Company Information: The researcher used two questions regarding companies (Nationality, and Nature of activity: service provider or manufacturer).

\section{Data analysis and hypothesis testing}

\subsection{Sample description}

The average age of participants was 42.7 ( $S D=11.41$ ). Males represented $79.7 \%$ of the sample. The average of participants experience at the company was 10.4 years $(\mathrm{SD}=7.88)$. The participants that holds Master degree represented $82.7 \%$ of the sample. European companies represented $33 \%$ of the sample. American companies and Arabian companies represented $(27 \%, 10 \%)$ respectively of the sample. Finally, Asian Companies represented (30\%) of the sample. Manufacturing companies represented $43 \%$ of the sample. Finally, Service provider companies represented $57 \%$ of the sample.

\subsection{Instrument validity and reliability}

The reliability of the survey instruments that were utilized in this study was tested based on Cronbach's alpha (see Table 1). It is held that an instrument which confirms a reliability score of 0.60 and above is generally considered adequate. However, a coefficient alpha of 0.70 at the minimum is generally acceptable for hypothesis testing. The results from table (1) show that the values of Cronbach's alpha for all variables are more than 0.70 (Hair et al. 2018). In order to ensure that the scale conveys an accurate representation of the construct, validity is measured using 
Table 1. Reliability of Survey Instrument $(\mathrm{n}=121)$ (source: author's calculations)

\begin{tabular}{|l|l|}
\hline \multicolumn{1}{|c|}{ Variable } & \multicolumn{2}{c|}{ Cronbach's Alpha } \\
\hline Explorative scenario & .86 \\
\hline Normative scenario & .81 \\
\hline Predictive scenario & .84 \\
\hline Financial Performance & .90 \\
\hline Customer Performance & .85 \\
\hline Learning and Growth & .88 \\
\hline Internal Business Processes & .89 \\
\hline Instrument as a whole & .82 \\
\hline
\end{tabular}

various forms including content, convergent, and discriminate validity (Hair et al. 2018).

\subsubsection{Content validity}

Expert reviews, such as opinions from the faculty members, and documented use of the scales from similar research studies, are used to measure content validity. based on the experts opinions the instrument has refined.

\subsubsection{Convergent validity}

Convergent validity was assessed by Dillon Goldstein's rho (composite reliability) and mean communalities (AVE) for each latent variable in the model.

"Average variance-extracted (AVE) attempts to measure the amount of variance that a latent variable component captures from its indicators relative to the amount due to measurement error" (Vinzi et al. 2010). An AVE of .50 or higher is a good rule of thumb and suggests adequate convergence and a good composite reliability score should be .70 or higher (Hair et al. 2018). All variables in the model returned acceptable composite reliability and AVE measures, indicating the manifest variables used in the instrument do, in fact, reflect their respective intended latent variable (Table 2).

\subsubsection{Discriminant validity}

Discriminant validity was established providing evidence that each construct is unique (see Table 3). A more rigorous test was applied to compare the AVEs of each latent variable. Table 3 demonstrates that they exceed all squared correlations between constructs (Fornell and Larcker 1981).

\subsection{Descriptive statistics}

The results from Table 4 show that multinational corporations use the scenario planning technique (Mean = 4.082). These results are logical, since the world has become more complex, thus the use of scenario planning technique has increased significantly during the recent years as
Table 2. Measurement Model $(\mathrm{n}=121)$ (source: author's calculations)

\begin{tabular}{|c|c|c|c|c|}
\hline $\begin{array}{c}\text { Constructs and Instrument } \\
\text { Variables }\end{array}$ & SL & $\begin{array}{l}\text { Critical } \\
\text { Ratio }^{a}\end{array}$ & $\underset{\mathrm{b}}{\mathrm{AVE}}$ & $\mathrm{CR}^{\mathrm{c}}$ \\
\hline Explorative Scenarios & & & 0.706 & 0.960 \\
\hline ES1 & $0.891^{*}$ & 47.13 & & \\
\hline ES2 & $0.837^{\star}$ & 36.97 & & \\
\hline ES3 & $0.862^{*}$ & 38.44 & & \\
\hline ES4 & $0.795^{\star}$ & 31.86 & & \\
\hline ES5 & $0.771^{\star}$ & 34.77 & & \\
\hline ES6 & $0.802^{*}$ & 30.58 & & \\
\hline Normative Scenarios & & & 0.618 & 0.893 \\
\hline NS1 & $0.844^{*}$ & 45.63 & & \\
\hline NS2 & $0.869^{*}$ & 37.11 & & \\
\hline NS3 & $0.814^{*}$ & 33.51 & & \\
\hline NS4 & $0.806^{*}$ & 30.09 & & \\
\hline NS5 & $0.783^{*}$ & 32.17 & & \\
\hline Predictive Scenarios & & & 0.747 & 0.940 \\
\hline PS1 & $0.877^{\star}$ & 41.62 & & \\
\hline PS2 & $0.738^{\star}$ & 33.16 & & \\
\hline PS3 & $0.759^{*}$ & 31.36 & & \\
\hline PS4 & $0.767^{\star}$ & 32.94 & & \\
\hline PS5 & $0.805^{\star}$ & 37.18 & & \\
\hline PS6 & $0.744^{*}$ & 31.90 & & \\
\hline Financial Performance & & & 0.605 & 0.918 \\
\hline FP1 & $0.706^{\star}$ & 30.22 & & \\
\hline FP2 & $0.744^{*}$ & 32.80 & & \\
\hline FP3 & $0.751^{\star}$ & 36.14 & & \\
\hline FP4 & $0.719^{*}$ & 31.47 & & \\
\hline FP5 & $0.737^{\star}$ & 34.02 & & \\
\hline Customer Performance & & & 0.624 & 0.901 \\
\hline $\mathrm{CP} 1$ & $0.748^{\star}$ & 39.77 & & \\
\hline $\mathrm{CP} 2$ & $0.763^{*}$ & 31.55 & & \\
\hline $\mathrm{CP} 3$ & $0.787^{\star}$ & 37.61 & & \\
\hline $\mathrm{CP} 4$ & $0.771^{\star}$ & 32.97 & & \\
\hline CP5 & $0.793^{*}$ & 35.14 & & \\
\hline Learning and Growth & & & 0.612 & 0.914 \\
\hline LG1 & $0.819^{*}$ & 40.22 & & \\
\hline LG2 & $0.857^{\star}$ & 34.62 & & \\
\hline LG3 & $0.790^{*}$ & 38.52 & & \\
\hline LG4 & $0.810^{*}$ & 37.19 & & \\
\hline LG5 & $0.769^{*}$ & 31.84 & & \\
\hline Internal Processes & & & 0.640 & 0.917 \\
\hline IP1 & $0.840^{*}$ & 39.70 & & \\
\hline IP2 & $0.880^{*}$ & 45.09 & & \\
\hline IP3 & $0.803^{*}$ & 40.13 & & \\
\hline IP4 & $0.798^{*}$ & 36.28 & & \\
\hline IP5 & $0.773^{*}$ & 34.47 & & \\
\hline
\end{tabular}

Notes: SL - standardized loading; AVE - average variance explained; CR composite reliability.

${ }^{*} p$-value $<.05$ for a two tailed test; ${ }^{a}$ values exceeding 1.96 represent levels of significance of $.05 ;{ }^{b}$ percentage of variance of the item explained by the latent variable; ${ }^{c}$ composite reliability $\rho$ (Werts et al. 1973). 
Table 3. Discriminant validity of the model $(\mathrm{n}=121)$ (source: author's calculations)

\begin{tabular}{|l|c|c|c|c|c|c|c|}
\hline & ES & NS & PS & FP & CP & LG & IP \\
\hline Explorative scenario (ES) & $(0.706)$ & & & & & & \\
\hline Normative scenario (NS) & 0.522 & $(0.618)$ & & & & & \\
\hline Predictive scenario (PS) & 0.441 & 0.471 & $(0.747)$ & & & & \\
\hline Financial Performance (FP) & 0.338 & 0.352 & 0.390 & $(0.605)$ & & & \\
\hline Customer Performance (CP) & 0.332 & 0.344 & 0.359 & 3.74 & $(0.624)$ & & \\
\hline Learning and Growth (LG) & 0.317 & 0.341 & 0.332 & 0.355 & 0.362 & $(0.612)$ & \\
\hline Internal Business Processes (IP) & 0.311 & 0.322 & 0.339 & 0.337 & 0.351 & 0.349 & $(0.640)$ \\
\hline
\end{tabular}

Notes: Squared correlations between latent constructs are presented in the table; values in parentheses are average variance extracted (AVEs) representing the percentage of manifest variables (items) explained by its latent construct. Discriminant validity of a measurement model requires squared correlations between the constructs to be smaller than the average variance extracted.

Table 4. The arithmetic means and standard deviations of respondent's answers on scenario planning items (source: author's calculations)

\begin{tabular}{|c|l|c|c|}
\hline Items & $\begin{array}{c}\text { Dimensions of Scenario } \\
\text { Planning }\end{array}$ & Mean & $\begin{array}{c}\text { Standard } \\
\text { Deviation }\end{array}$ \\
\hline $1-6$ & Explorative Scenarios & 4.107 & 0.941 \\
\hline $7-11$ & Normative Scenarios & 4.180 & 0.933 \\
\hline $12-17$ & Predictive Scenarios & 3.958 & 1.07 \\
\hline $1-17$ & Total Average of Means & 4.082 & 0.981 \\
\hline
\end{tabular}

a technique to long-term planning in constantly changing environments that characterized by unsteady and unpredictable futures.

The results from Table 5 show that multinational corporations achieved high level of strategic performance (Mean $=4.086)$. These results are logical due to the role of scenario planning in simulating the developments and changes in the business environment. Thus helps MNCs to achieve their goals efficiently and effectively.

Table 5. The arithmetic means and standard deviations of respondent's answers on strategic performance items (source: author's calculations)

\begin{tabular}{|c|l|c|c|}
\hline Items & $\begin{array}{c}\text { Dimensions of } \\
\text { Strategic Performance }\end{array}$ & Mean & $\begin{array}{c}\text { Standard } \\
\text { Deviation }\end{array}$ \\
\hline $18-22$ & Financial Perspective & 3.942 & 0.969 \\
\hline $23-27$ & Customer Perspective & 4.074 & 0.991 \\
\hline $28-2$ & Learning and Growth & 4.166 & 1.071 \\
\hline $33-37$ & Internal Processes & 4.162 & 0.944 \\
\hline $18-37$ & $\begin{array}{l}\text { Total Average of } \\
\text { Means }\end{array}$ & 4.086 & 0.994 \\
\hline
\end{tabular}

\subsection{Hypotheses testing}

Pearson correlation and the partial least squares (PLS) methodology for factor analysis and path modelling was used to test the study hypotheses. The results from Table 6 show that financial performance was both positively and significantly correlated $(\mathrm{r}=.531, \mathrm{p}<.01$.) with the scenario
Table 6. Pearson's Correlation $(\mathrm{n}=121)$ (source: author's calculations)

\begin{tabular}{|l|c|c|c|c|c|}
\hline & 1 & 2 & 3 & 4 & 5 \\
\hline $\begin{array}{l}1 \text { Financial } \\
\text { Performance }\end{array}$ & & & & & \\
\hline $\begin{array}{l}2 \text { Customer } \\
\text { Performance }\end{array}$ & $.46^{\star *}$ & & & & \\
\hline $\begin{array}{l}3 \text { Learning and } \\
\text { Growth }\end{array}$ & $.219^{\star *}$ & $.38^{\star *}$ & & & \\
\hline $\begin{array}{l}4 \text { Internal } \\
\text { Business } \\
\text { Processes }\end{array}$ & $.228^{\star *}$ & $.243^{* *}$ & $.48^{\star *}$ & & \\
\hline $\begin{array}{l}5 \text { Scenario } \\
\text { Planning }\end{array}$ & $.531^{\star *}$ & $.590^{\star *}$ & $.673^{\star *}$ & $.622^{\star *}$ & \\
\hline
\end{tabular}

${ }^{\star} p<.05 .{ }^{* *} p<.01$

planning. Additionally, the results of the correlation indicate that customer performance was both positively and significantly correlated with the scenario planning $(\mathrm{r}=.590$, $. \mathrm{p}<.01)$. As well, the results show that learning and growth was both positively and significantly correlated $(\mathrm{r}=.673$, $\mathrm{p}<.01$.) with the scenario planning. Finally, the results of the correlation indicate that internal business processes was both positively and significantly correlated with the scenario planning $(\mathrm{r}=.622, \mathrm{p}<.01)$. These results were confirmed by the partial least squares (PLS) methodology for factor analysis and path modelling (see Table 7).

\section{Results discussion}

The current study empirically tested the relationship between scenario planning and the strategic performance of multinational corporations in Jordanian context.

The findings of this study pointed out that scenario planning has a significant positive relationship with financial performance and it is similar with certain previous studies which found that scenario planning can be used as a tool to improve financial performance (Phelps et al. 2001). Additionally, the findings indicated that scenario planning 
Table 7. Study Hypotheses Results: Path Estimates ( $\mathrm{n}=121)$ (source: author's calculations)

\begin{tabular}{|l|c|c|c|l|}
\hline \multicolumn{1}{|c|}{$\begin{array}{c}\text { Study } \\
\text { Hypotheses }\end{array}$} & DSE $^{1}$ & $\begin{array}{c}\text { Critical } \\
\text { Ratio }\end{array}$ & $\begin{array}{c}\text { Confidence } \\
\text { Range }^{2}\end{array}$ & Conclusion \\
\hline H1: SP => FP & $0.491^{\star}$ & 18.177 & $0.395,0.493$ & Supported \\
\hline H2: SP => CP & $0.459^{*}$ & 17.804 & $0.388,0.485$ & Supported \\
\hline H3: SP => LG & $0.451^{*}$ & 17.790 & $0.381,0.479$ & Supported \\
\hline H4: SP => IBP & $0.446^{*}$ & 17.714 & $0.377,0.474$ & Supported \\
\hline $\begin{array}{l}\text { Goodness of } \\
\text { fit (GoF): } \\
\text { Absolute GoF }\end{array}$ & 0.591 & $\begin{array}{c}\text { Relative } \\
\text { GoF }\end{array}$ & 0.918 & \\
\hline
\end{tabular}

Note: SP - Scenario Planning; FP - Financial Performance; CP Customer Performance; LG - Learning and Growth; IBP - Internal Business Processes.

1 - Direct Standard Effect

${ }^{2 *} p$-value $<.05$ for a two-tailed test

has a significant positive relationship with customer performance and it is in line with previous studies (Kuye and Oghojafor 2011). Moreover, the findings indicated that scenario planning has a significant positive relationship with internal business processes. Many previous research and studies found that scenario planning is regarded as the most important element that influence the internal business processes within organization (Ramirez and Wilkinson 2016, Sarpong and Maclean 2011, van der Heijden 1996). As well, the findings revealed that the scenario planning has a significant positive relationship with learning and growth and it is in line with previous studies (Arafet and Ali 2018, Bennett et al. 2016, Burt et al. 2017, Glick et al. 2012, Schwartz 1996, van der Heijden 1996). Finally, the findings of this study in general demonstrated that the scenario planning has a significant positive relationship with strategic performance.

However, the results can be interpreted based on the following argument: by learning and innovation the organization, will improve its abilities or create new ones that will facilitate a better performance in internal processes, increasing the efficiency, effectiveness and productivity. Since improved internal processes will provide companies the ability to better fulfil customers, an increase in customer satisfaction is expected. In the long run increased customer satisfaction and improved internal processes will result in better financial performance.

\section{Practical implications}

Based on the findings the study recommends that:

- First, Managers should apply scenario planning practices to enhance the levels of strategic performance in their companies.

- Second, Managers should raise the awareness of their employees regarding the importance of both scenario planning and strategic performance.
- Third, Managers should provide their employees with adequate training courses that specialized in scenario planning in order to acquire the knowledge and build their skills in this field.

- Fourth, Managers should use diagnostic instruments that developed by previous research to assess a company's strategic performance and scenario planning practices, identify managerial practices that need to be implemented or improved, and determine the resources that might realistically be required to build a better scenario planning process and promote strategic performance.

\section{Limitations}

Despite important contributions from this study, several limitations remain:

- First, the study was conducted in the Multinational Corporations operating in Jordan. Therefore, the results may not generalize to other sectors.

- Second, the current study focused on the perceptions of members within a particular managerial level in a limited number of organizations.

\section{Recommendations for future researches}

Much more research and studies need to be performed in this budding subject. Much more subjects relate to scenario planning need to be made. Links among scenario planning and another organizational topics and outcomes need to be searched. As the study of scenario planning continues to arise more fully, it may help to better understand the effect of this model on prophesying strategic flexibility, strategic agility, organizational ambidexterity and toward creating competitive advantage for the organization in general.

\section{Conclusions}

The findings of the current study provide valuable insight to multinational corporation as well as to management academics. Multinational corporations' commitment to scenario planning indicates their higher level of strategic performance. These findings are consistent with the theory and findings of the other studies.

First, this exploratory study supported the relationship between scenario planning and strategic performance based on the balanced scorecard perspectives. Second, the results suggest that multinational corporation must do well in scenario planning to achieve high strategic performance. Finally, the findings involving managers of multinational corporation operating in Jordan indicate that the multinational corporations with right scenario techniques can achieve high strategic performance in developing countries as well as in developed ones. 
In summary, the current study answers the call of researchers to explore how scenario planning might influence the strategic performance. The study explored this issue among multinational corporations because they have a particularly high need to overcome uncertainty state that harms their strategic performance.

\section{References}

Abdulai MM, Robert HE, Amfo AP (2018) Service innovation and customer satisfaction: the role of customer value creation. European Journal of Innovation Management 21 (3): 402-422. https://doi.org/10.1108/EJIM-09-2017-0117

Al-Maaitah N (2018) The role of justice in achieving long-term buyer-supplier relationship: the case of Jordanian manufacturing sector. International Review of Management and Marketing 8 (2): 109-117.

Aliya B, Maheen M (2017) The impact of organizational capabilities on organizational performance: empirical evidence from banking industry of Pakistan. Pakistan Journal of Commerce and Social Sciences 11 (1): 408-438.

Al-Tarawneh KA (2018) The possibility of applying the balanced scorecard a tool of evaluating the strategic performance of the Jordanian private universities (field study from the perspective of workers in private universities in Jordan). Academy of Marketing Studies Journal 22 (1): 1-25.

Arafet B, Ali S (2018) Scenario planning: an investigation of the construct and its measurement. Journal of Forecasting 37 (4): 489-505. https://doi.org/10.1002/for.2515

Azalia J, Stein W (2017) Strategic planning and scenario planning in public institutions: the case study of Pacific Alliance. FIIB Business 6 (3): 26-37. https://doi.org/10.1177/ 2455265820170306

Argueta CM, Agudelo I, Soto Cardona OC (2016) Scenario planning: a case study in a Colombian logistics consulting firm. Estudios Gerenciales 32 (138): 96-107. https://doi. org/10.1016/j.estger.2015.12.004

Bennett NJ, Kadfak A, Dearden P (2016) Community-based scenario planning: a process for vulnerability analysis and adaptation planning to social-ecological change in coastal communities. Environ Dev Sustain 18: 1771-1799. https:// doi.org/10.1007/s10668-015-9707-1

Bennett N, Lemoine J (2014) What VUCA Really Means for You. Harvard Business Review 92 (1/2): 1.

Booth R (1996) Accountants do it by proxy. Management Accounting 74 (5): 48-61.

Borjeson L, Hjoer M, Dreborg K, Ekvall T, Finnveden G (2006) Scenario types and techniques: towards a user's guide. Futures 38: 723-739. https://doi.org/10.1016/j.futures.2005.12.002

Bowman G, Mackay RB, Masrani S, Mckiernan P (2013) Storytelling and the scenario process: understanding success and failure. Technological Forecasting and Social Change 80 (4): 735-748. https://doi.org/10.1016/j.techfore.2012.04.009

Bradfield R, Derbyshire J, Wright G (2016) The critical role of history in scenario thinking: augmenting causal analysis within the intuitive logics scenario development methodology. Futures 77 (1): 56-66.
Bradfield R, Wright G, Burt G, Cairns G, van der Heijden K (2005) The origins and evolution of scenario techniques in long range business planning. Futures 37 (8): 795-812. https:// doi.org/10.1016/j.futures.2005.01.003

Burt G, Mackay DJ, Van der Heidjen K, Verheijdt C (2017) Openness disposition: readiness characteristics that influence participant benefits from scenario planning as strategic conversation. Technological Forecasting and Social Change 124 (1): 16-25. https://doi.org/10.1016/j.techfore.2016.11.024

Burt G, van der Heijden K (2003) First steps: towards purposeful activities in scenario thinking and future studies. Futures 35: 1011-1026. https://doi.org/10.1016/s0016-3287(03)00065-X

Burt G, Wright G, Bradfield R, Cairns G, van der Jeijden K (2006) The role of scenario planning in exploring the environment in view of the limitations of PEST and Its derivatives. International Studies of Management and Organizations 36 (3): 78-97. https://doi.org/10.2753/IMO0020-8825360303

Burt G, Chermack TJ (2008) Learning with scenarios: summary and critical issues. Advances in Developing Human Resources 10 (2): 285-295. https://doi.org/10.1177/1523422307313334

Chakravarthy BS (1986) Measuring strategic performance. Strategic Management Journal 7 (5): 437-458. https://doi. org/10.1002/smj.4250070505

Chandler AD (1962/1998) Strategy and structure: chapters in the history of the American Industrial Enterprise. Cambridge: MIT Press.

Chen FH, Hsu TS, Tzeng GH (2011) A balanced scorecard approach to establish a performance evaluation and relationship model for hot spring hotels based on a hybrid MCDM model combining DEMATEL and ANP. International Journal of Hospitality Management 30: 908-932. https://doi.org/10.1016/j. ijhm.2011.02.001

Chermack TJ (2011) Scenario planning in organizations: how to create, use, and assess scenarios. San Francisco: Berrett-Koehler.

Chermack TJ, Coons LM, O’barr G, Khatami S (2017) The effects of scenario planning on participant reports of resilience. European Journal of Training and Development 41 (4): 306-326. https://doi.org/10.1108/EJTD-08-2015-0068

Chermack TJ, Lynham SA (2002) Definitions and outcome variables of scenario planning. Human Resource Development Review 1 (3): 366-383. https://doi.org/10.1177/ 1534484302013006

Chermack TJ, Lynham SA, Ruona WEA (2001) A review of scenario planning literature. Future Research Quarterly 17 (2): 7-31.

Chermack TJ, Lynham SA, van der Merwe L (2006) Exploring the relationship between scenario planning and perceptions of learning organization characteristics. Futures 38 (7): 767-777. https://doi.org/10.1016/j.futures.2005.12.010

Chong IG, Jun, CH (2005) Performance of some variable selection methods when Multicollinearity is present. Chemo metrics and Intelligent Laboratory Systems 78: 103-112. https://doi. org/10.1016/j.chemolab.2004.12.011

Chung HF (2011) Market orientation, guanxi, and business performance. Industrial Marketing Management 40 (4): 522-533. https://doi.org/10.1016/j.indmarman.2010.12.008

Chung HF, Yang Z, Huang PH (2015) How does organizational learning matter in strategic business performance? The contingency role of guanxi networking. Journal of 
Business Research 68 (6): 1216-1224. https://doi.org/10.1016/j. jbusres.2014.11.016

Clarke CJ (1987) Acquisitions-techniques for measuring strategic fit. Long Range Planning 20 (3): 12-18. https://doi. org/10.1016/0024-6301(87)90067-7

Collis DJ, Montgomery CA (1995) Competing on resources: strategy in the 1990s. Harvard Business Review (July-Aug): 118-128. https://doi.org/10.1016/b978-0-7506-7088-3.50005-X

Cox Landolt S (2000) Flexible mindset. Credit Union Management 23 (23): 65-79.

Drew SAW (2006) Building technology foresight: using scenarios to embrace innovation. European Journal of Innovation Management 9 (3): 241-257.

Durance P, Godet M (2010) Scenario building: uses and abuses. Technological Forecasting and Social Change 77 (9): 14881492. https://doi.org/10.1016/j.techfore.2010.06.007

Fornell C, Larcker D F (1981) Evaluating structural equation models with unobservable variables and measurement error. Journal of Marketing Research 18 (1): 39-50. https:// doi: $10.2307 / 3151312$

Glick MB, Chermack TJ, Luckel H, Gauck BQ (2012) Effects of scenario planning on participant mental models. European Journal of Training and Development 36 (5): 488-507. https:// doi:10.1108/03090591211232066

Grigoroudis E, Orfanoudaki E, Zopounidis C (2012) Strategic performance measurement in a healthcare organization: a multiple criteria approach based on balanced scorecard. Omega 40 (1): 104-119. https://doi.org/10.1016/j.omega.2011.04.001

Haasnoot M, Kwakkel J, Walker W, Maat JT (2013) Dynamic adaptive policy pathways: a method for crafting robust decisions for a deeply uncertain world Global Environmental Change 23 (2): 485-498. https://doi.org/10.1016/j.gloenvcha.2012.12.006

Hair J, Blackman WC, Anderson ER, Babin BJ (2018) Multivariate data analysis (7th ed) New Jersey: Cengage Learning.

Hartmann D, Stillings C (2015) Using scenarios in multinational companies across geographic distances - a case from the chemical industry. Foresight 17 (5): 475-488. https://doi. org/10.1108/FS-11-2014-0076

Hiltunen E (2009) Scenarios: process and outcome. Journal of Futures Studies 13 (3): 151-152 http://jfsdigital.org/wp-content/ uploads/2014/01/133-S13.pdf

Hojer M, Ahlroth S, Dreborg KH, Ekvall T, Finnveden G, Hjelm O, Hochschorner E, Nilsson M, Palm V (2008) Scenarios in selected tools for environmental systems analysis. Journal of Cleaner Production 16: 1958-1970. https://doi.org/10.1016/j. jclepro.2008.01.008

Inayatullah S (2009) Questioning scenarios. Journal of Futures Studies 13 (3): 75-80 http://jfsdigital.org/wp-content/ uploads/2014/01/133-S01.pdf

Jusoh R, Ibrahim DN, Zainuddin Y (2008) The performance consequence of multiple performance measures usage: evidence from the Malaysian manufacturers. International Journal of Productivity and Performance Management 57 (2): 119-136. https://doi.org/10.1108/17410400810847393

Kahane A (2012) Transformative scenario planning: changing the future by exploring alternatives. Strategy \& Leadership 40 (5): 19-23. https://doi.org/10.1108/10878571211257140
Kaplan R, Norton D (1992) The balanced scorecard - measures that drive performance. Harvard Business Review 70 (1): 71 79 https://hbr.org/1992/01/the-balanced-scorecard-measuresthat-drive-performance-2

Kaplan R, Norton D (1996) The balanced scorecard-translating strategy into action. Boston: Harvard Business School Press.

Kaplan R, Norton D (2001) The strategy-focused organization: how balanced scorecard companies thrive in the new business environment. Boston: Harvard Business School Press.

Kaplan R, Norton D (2004) Strategy maps: converting intangible assets into tangible outcomes. Boston: Harvard Business School Press.

Kim K, Watkins KS, Lu Z (2017) The impact of a learning organization on performance: Focusing on knowledge performance and financial performance. European Journal of Training and Development 41 (2): 177-193.

Kuye OL, Oghojafor BA (2011) Scenario planning as a recipe for corporate performance: the Nigerian manufacturing sector experience. International Journal of Business and Management 6 (12): 170-179.

Kyei DA, Bayoh AT (2017) Innovation and customer retention in the Ghanaian telecommunication industry. International Journal of Innovation 5 (2): 171-183. https://doi.org/ 10.5585/ iji.v5i2.154

Lindgren M, Bandhold H (2009) Scenario planning: the link between future and strategy. New York: Palgrave Macmillan.

Madison K, Runyan RC, Swinney JL (2014) Strategic posture and performance: revealing differences between family and nonfamily firms. Journal of Family Business Strategy 5 (3): 239-251. https://doi.org/10.1016/j.jfbs.2013.11.006

Malaska P, Malmivirta M, Meristo T, Hansen SO (1984) Scenarios in Europe-who uses them and why?. Long Range Planning 17: 45-49. https://doi.org/10.1016/0024-6301(84)90036-0

Martino JP (2003) A review of selected recent advances in technological forecasting. Technological Forecasting and Social Change 70 (8): 719-733. https://doi.org/10.1016/s00401625(02)00375-X

Miles RE, Snow CC (1978) Organizational strategy, structure and process. New York: McGraw-Hill.

Mitchell F, Nielsen LB, Nørreklit H, Nørreklit L (2013) Scoring strategic performance: a pragmatic constructivist approach to strategic performance measurement. Journal of Management \& Governance 17 (1): 5-34. https://doi.org/10.1007/ s10997-012-9216-7

O'Brien FA, Meadows M (2013) Scenario orientation and use to support strategy development. Technological Forecasting and Social Change 80 (4): 643-656. https://doi.org/10.1016/j. techfore.2012.06.006

Oliver JJ, Parrett E (2017) Managing uncertainty: harnessing the power of scenario planning. Strategic Direction 33 (1): 5-6. https://doi.org/10.1108/SD-09-2016-0131

Phadnis S, Caplice C, Sheffi Y (2016) How scenario planning influences strategic decisions. MIT Sloan Management Review 57 (4): 24-27 http://mitsmr.com/1Vmgocb

Phelps R, Chan C, Kapsalis SC (2001) Does scenario planning affect performance? Two exploratory studies. Journal of Business Research 51 (3): 223-232. https://doi.org/10.1016/ s0148-2963(99)00048-x 
Pinero CJ (2002) The balance scorecard: an incremental approach model to health care management. Journal of Health Care Finance 28 (4): 69-80.

Porter ME (1980) Competitive strategy: techniques for analyzing industries and competitors. New York: Free Press.

Porter ME (1985) Competitive advantage: creating and sustaining superior performance. New York: Free Press.

Porter ME (1998) Competitive advantage. New York: Free Press. https://doi.org/10.1007/978-1-349-14865-3

Prahalad CK, Hamel G (1990) Core competence of the corporation. Harvard Business Review (May-June): 79-91 https:// hbr.org/1990/05/the-core-competence-of-the-corporation

Prieto IM, Revilla E (2006) Learning capability and business performance: a non-financial and financial assessment. The Learning Organization 13 (2/3): 166-185. https://doi. org/10.1108/09696470610645494

Puthenveetil JP (2016) An assessment the role of scenario based anticipatory organizational learning in strategy development an organizational development perspective. Doctoral dissertation. Available from ProQuest Dissertations \& Theses Global database.

Ramirez R, Wilkinson A (2016) Strategic reframing: the oxford scenario planning approach. Oxford: Oxford University Press. https://doi.org/10.1093/acprof:oso/9780198745693.001.0001

Rigby D, Bilodeau B (2007) Selecting management tools wisely. Harvard Business Review (December): 20-22 https://hbr. org/2007/12/selecting-management-tools-wisely

Ringland G (1998) Scenario planning: managing for the future. New York: John Wiley.

Robbins GC (1995) Scenario planning: a strategic alternative. Public Management 77 (3): 4-15.

Sarpong D, Maclean M (2011) Scenario thinking: a practice-based approach for the identification of opportunities for innovation. Futures 43: 1154-1163. https://doi.org/10.1016/j. futures.2011.07.013

Schoemaker FJH (1995) Scenario planning: a tool for strategic thinking. Sloan Management Review: 25-40. https://doi. org/10.1016/0024-6301(95)91604-0

Schulaka C (2017) Dennis stearns on super trends, predicting change, and scenario planning. Journal of Financial Planning 30 (1): 14-18. https://www.onefpa.org/

Schwartz P (1996) The art of the long view. New York: Doubleday.

Senge PM, Roberts C, Ross RB, Smith BJ, Kleiner A (1994) The fifth discipline field book: strategies and tools for building a learning organization. New York: Doubleday Currency.

Sharabati A, Fqaha S (2014) The impact of strategic management on the jordanian pharmaceutical manufacturing organizations' business performance. International Review of Management and Business Research 3 (2): 668-687. http://www. irmbrjournal.com/papers/1399183826.pdf

Sim K, Koh H (2002) Balanced scorecard: a rising trend in strategic performance measurement. Measuring Business Excellence 5 (2): 18-26. https://doi.org/10.1108/13683040110397248
Simons R (1990) The role of management control systems in creating competitive advantage: new perspectives. accounting organizations and society 15 (1-2): 127-143. https://doi. org/10.1016/0361-3682(90)90018-P

Sosik JJ, Kahai SS, Piovoso MJ (2009) Silver bullet or voodoo statistics?: A primer for using the partial least squares data analytic technique in group and organization research. Group \& Organization Management 34 (1): 5-36. https://doi. org/10.1177/1059601108329198

Strauss JD, Radnor M (2016) Road mapping for dynamic and uncertain environments. Research Technology Management 47 (2): 51-58. https://doi.org/10.1080/08956308.2004.11671620

Summit E (2002) Foreign direct investment: a lead driver for sustainable development? Paper presented at Economic Summit. _www.earthsummit2002.org/es/issues/FDI/fdi.htm.

Swanson E (1998) Swanson reviews: scenario planning for libraries edited by Joan Giesecke. The booklist 94 (21): 1853-1864.

Van der Heijden K (1996) Scenarios: the art of strategic conversation. England: John Wiley and Sons.

Vinzi VE, Chin WW, Henseler J, Wang H (2010) Handbook of partial least squares: concepts, methods and applications. Berlin, Germany: Springer-Verlag.

Visser MP, Chermack TJ (2009) Perceptions of the relationship between scenario planning and firm performance: a qualitative study. Futures 41 (9): 581-592. https://doi.org/10.1016/j. futures.2009.04.010

Wack P (1985) Scenarios: shooting the rapids. Harvard Business Review 63 (6): 139-150.

Weng M, Ha J, Wang Y, Tsai C (2012) A study of the relationship among service innovation, customer value and customer satisfaction: an empirical study of the hotel industry in Taiwan. International Journal of Organizational Innovation 4 (3): $98-112$.

Werts CE, Joreskog KG, Linn RL (1973) Identification and estimation in path analysis with unmeasured variables. American Journal of Sociology 78 (6): 1469-1484. https:// doi.org/10.1086/225474

Wheelen TL, Hunger JD (2012) Strategic management and business policy: toward achieving sustainability (13th ed) Upper Saddle River, N.J: Pearson Prentice Hall.

Wood W (1997) So where do we go from here? Across the Board 34 (3): 44-49.

Wu SI, Hung JM (2008) A performance evaluation model of CRM on nonprofit organizations. Total Quality Management \& Business Excellence 19 (4): 321-342. https://doi. org/10.1080/14783360701591978

Zahradnícková L, Vacík E (2014) Scenarios as a strong support for strategic planning. Procedia Engineering 69: 665-669. https://doi.org/10.1016/j.proeng.2014.03.040

Zou S, Cavusgil ST (2002) The GMS: a broad conceptualization of global marketing strategy and its effect on firm performance. Journal of Marketing 66 (4): 40-56. https://doi.org/10.1509/ jmkg.66.4.40.18519 


\section{APPENDIX A}

\section{Survey Instrument}

\section{Scenario Planning}

Listed below are some statements about scenario planning. Please indicate your response by writing the number that best describes your level of agreement with each of the statement.

$\begin{array}{ccccc}\text { Strongly Agree } & \text { Agree } & \text { Neutral } & \text { Disagree } & \text { Strongly Disagree } \\ 5 & 4 & 3 & 2 & 1\end{array}$

1) The answers of the question (what can happen to the development of external factors) are used in the planning process.

2) The answers of the question (what can happen if we act in a certain way) are used in the planning process.

3) The company explores the future from a multiple perspectives.

4) The company develops a set of scenarios that illustrate different potential developments.

5) The company is able to respond to various kinds of developments in the business environment.

6) The company determines the possible consequences of strategic decisions.

7) Our future targets are well defined.

8) The company is able to achieve its targets in efficient manner.

9) The answers of the question (how can the target be met, by adjustments to current situation) are used in the planning process.

10) The answers of the question (how can a target be met, when prevailing structure blocks necessary changes) are used in the planning process.

11) The company discovers the factors that may be crucial for reaching the targets.

12) The company depends on its historical information to predict what will happen in the future.

13) What-if questions are used to focus on events in the near future.

14) The company identifies the conditions in which the probability of occurrence is likely to be significant.

15) The company determines the conditions that will occur based on close future events.

16) In our scenarios, we focus on identifying the developments that depend on a certain well-specified external events and/or internal decisions.

17) Different kinds of predictions are used to highlight problems that will arise if current trends continue in the future.

\section{Strategic Performance}

Listed below are some statements about strategic performance. Please indicate your response by writing the number that best describes your level of agreement with each of the statement.

Strongly Agree 5
Agree

4
Neutral

3

Disagree
2

2
Strongly Disagree 1

18) The rate of return on assets has increased.

19) Revenue growth rate is high.

20) Net profit ratio has increased.

21) Dividends to share have increased.

22) The wealth of our shareholders has increased.

23) Our customer satisfaction level is high.

24) The number of our customers complaints is low.

25) Our customers loyalty level is high.

26) The company adds a value to customers.

27) The company image has improved.

28) Innovation capabilities have increased.

29) Employees' ability to manage emergencies has increased.

30) Creative ideas to develop performance have increased.

31) Employees' productivity has increased.

32) The company applies the latest technology of R\&D.

33) The company introduces new products in suitable time. 
34) The company is able to retain existing customers.

35) The company is able to solve problems in effective manner.

36) The company develops the processes continuously.

37) The company management efficiency has increased.

\section{Demographic Information}

Please provide the following information:

38) Your gender

39) I am ___ years old.

40) Years worked at this company

41) Your education

42) The nationality of my company

43) The nature of my company activity: A) Manufacturer

B) Service provider 